\title{
高齢な女性腰椎圧迫骨折患者における \\ 腰部体幹筋の脂肪浸潤程度について \\ Characteristics of fat infiltration in the lumbar trunk muscles in elderly female patients with lumbar compression fracture.
}

\author{
藤本 貴大 ${ }^{1}$, 田中 繁治 ${ }^{2}$ \\ TAKahiro Fujimoto1), Shigehard Tanaka ${ }^{2)}$

\begin{abstract}
要旨：高齢女性腰椎圧迫骨折患者を対象に，腰部多裂筋（以下； LM）打よび金柱起立筋 (以下； $\mathrm{ESM}$ )，大腰筋（以下；PM）の脂肪浸潤率を定量的な方法で計測し，筋肉の脂 肪浸潤程度に特徴が見られるかを検討した。計測には，MRI 画像を利用した。MRI 画像 は，第 1 腰椎から第 1 仙骨上縁までの椎体上縁と椎体中間位計 11 䇢所を利用した。脂肪浸 潤率は, 各筋の横断面積とその面積に占める脂肪浸潤面積の比率とした。計測には, Image J1.47を利用した。結果，全11箇所の LM および ESM の脂肪浸潤率は，13.9 26.5\%で あった。PM は0.4 2.0\%であり, LM および ESM と比較し有意に低值であった $(\mathrm{p}<0.01$ ～0. 001)。各筋の脂肪浸潤率と BMI とは，有意な相関関倸は認められなかった。同一筋 内全11箇所に扔ける脂肪浸潤率の多重比較では，有意差は認めなかった。また，骨折部と 非骨折部に分け比較した場合の結果も有意差は認めなかった。以上のことより，本研究の 高齢女性腰椎圧迫骨折患者における LM および ESM の脂肪浸潤率は，限局的ではなく腰 椎全域で10\%以上生じていることが明らかとなった。
\end{abstract}

キーワード：腰椎圧迫骨折，腰椎多裂筋，脂肪浸潤率，高齢女性

\begin{abstract}
The aim of this study was to examine the fat infiltration ratio in the lumbar multifidus (LM), erector spinae muscles (ESM), and psoas major (PM) in elderly female patients with lumbar compression fracture. Subjects were fourteen elderly females aged 65 or over who have been diagnosed with lumbar compression fracture. A total of 11 levels per individual, corresponding to the axial sectional planes through the upper endplate and middle endplate of each lumbar vertebra (L) and the upper margin of the first sacral vertebra (S), were measured LM, ESM, and PM cross-sectional area (CSA). The images were transferred to the Image J. The fat infiltration ratio was a value obtained by dividing the fat infiltration area at CSA (muscle and fat). Range of the fat infiltration ratio in LM and ESM were 13.9 26.5\%, and that of PM was 0.4 2.0\%. The fat infiltration ratio in LM and ESM were significant higher than that of PM $(\mathrm{p}<0.01 \sim 0.001)$. The fat infiltration ratio of each muscle did not demonstrate significant correlations with body mass index. There were no significant differences in the fat infiltration ratio of 11 levels in the same muscle. The difference in fat infiltration ratio were compared by classifying the fracture and nonfracture. There were no significant differences in the mean, the left and the right in both each muscles. These results suggested that LM and ESM fat infiltration rate in patients with lumbar compression fracture of this study was observed as a whole rather than a focal fatty infiltration.
\end{abstract}

Key words: Lumbar compression fracture, the lumbar multifidus, fat infiltration rate, Elderly female

受付日：2015年12月21日，採択日：2016年 7 月28日

社会医療法人金田病院 リハビリテーション科：岡山県真庭市西原63（テ719-3193）TEL：0867-52-1191

E-mail : f5j1m4t@gmail.com

Department of Rehabilitation Kaneda Hospital, Medical Corporation, Nishibara 63, Maniwa-city, Okayama 719-3193, Japan.

2) 専門学校川崎リハビリテーション学院 理学療法学科

Department of Physical Therapy, Kawasaki Junior College of Rehabilitation 


\section{I 。はじめに}

椎体圧迫骨折は高齢者に多く, 疼痛や椎体変形が生 じれば脊柱アライメントの異常を引き起こし，日常生 活動作能力の低下 ${ }^{1,2)}$, 生活の質低下 ${ }^{3,4)}$ に関連し,さ らに生命予後の短縮5に影響することが報告されてい る。

通常, 脊椎は生理的彎曲を形成し, この生理的彎曲 は姿勢を維持するうえで最もエネルギー効率が良いと される。福田ら ${ }^{6}$ は, 高齢女性の腰椎前彎角度減少に より脊椎全体の前傾角度の増加, 胸椎の後彎角度や仙 骨後彎角度の増加と関連し, 歩行機能低下にも関連す ると報告している。そのため, 脊柱アライメントにお いて，適切な腰椎前彎維持は重要と考えられる。

また，脊柱抢よび骨盤アライメントは，筋活動とも 関連するとされ7), 腰椎を含む椎体圧迫骨折治癒後の 運動療法に背筋運動が有効とされている。背筋運動は, 背筋力を上昇させ椎体骨折率を有意に低くすること， 生理的彎曲の再建に加え疼痛遷延の改善に有効とされ $3^{8)}$ 。さらに，体幹の中でも腰椎骨盤領域には体重や 重力によって産生される大きな力が加わり，その負荷 に対抗し腰椎の安定性を保つためには筋力が必要とな る。したがって，腰椎圧迫骨折患者の腰椎安定性には， 骨と勒帯のみだけでなく筋による関与が重要と考えら れる。

これまで筋量や筋力は身体活動量や加齢との関連が 示されており，その評価方法には非侵襲的な方法とし て CT 法や MRI 法, 超音波法による筋横断面積 (cross sectional area 以下；CSA） ${ }^{9-11}$ が使用されている。ま た近年，実質的な筋収縮組織以外の脂肪組織増加とな る質的変化も筋萎縮とともに筋力と負の相関関係が認 められている ${ }^{12-14)}$ 。加えて, 筋肉の脂肪浸潤は機能障 害とも関連する可能性が報告され ${ }^{15)}$ ，高齢者の大腿四 頭筋の脂肪浸潤増加は, 移動能力の制限とも関連する ことが報告されている ${ }^{16)}$ 。そのため，脊椎安定性に関 わる体幹筋においても質的変化となる脂肪浸潤程度を 評価することは重要と考えられる。

体幹筋の脂肪浸潤に関して, 加齢により腰部脊柱起 立筋で脂肪浸潤しやすいことが報告されている 筋群の中で多裂筋は，椎体分節的安定性に重要な体幹 深層筋とされている。腰痛や椎間板ヘルニア患者では， 疼痛部位となる腰椎高位の片側で限局的な腰部多裂筋 の脂肪浸潤を認め, 脊柱起立筋ではこの限局的な脂肪 浸潤は認められていない18)。これには，腰部多裂筋は， 腰神経後枝内側枝が単根性に支配されている解剖学的
特徵が一つに影響している可能性も考えられる。つま り, 腰部多裂筋の CSA の評価については, 骨折や関 節損傷部により限局的な形態的変化が生じることが推 測される。そのため, 腰部多裂筋の脂肪浸潤評価には, 各椎体に加え左右差についても比較することも重要と 考える。

腰椎圧迫骨折患者を対象とした背筋群の脂肪浸潤に ついて Kim ら ${ }^{199}$ は, MRI 画像の第 4 腰椎 5 腰椎間の 画像を用いて, 腰部多裂筋の脂肪浸潤程度を半定量的 な目視によるグレード分類 (軽度；10\%未満, 中等度； 10 50\%未満，重度； $50 \%$ 以上）で検討している。そ の結果，春椎圧迫骨折患者は健常者と比へ腰部多裂筋 の脂肪浸潤が中等度に分類された者が有意に多かった と報告している。つまり，腰椎圧迫骨折患者の多裂筋 脂肪浸潤程度は高いことが考えられる。しかしながら， 腰椎圧迫骨折患者を対象とし, 腰部多裂筋の各椎体お よび左右それぞれでの定量的な計測による検討はされ ていない。そこで，各腰椎での腰部多裂筋の質的変化 がどの程度生じているかという基礎的な理解を得るこ とは重要であると考えられる。本研究では, MRI 画 像を利用し, 腰椎圧迫骨折患者の腰部多裂筋, 腰部脊 柱起立筋, 大腰筋の脂肪浸潤程度を各腰椎左右別に定 量的な方法で計測し，腰椎全域の脂肪浸潤程度の特徵 を検討することとした。

\section{II. 対象と方法}

\section{1. 対 象}

対象は，受傷前に生活機能の自立していた65歳以上 の女性で, 初発の単椎体腰椎圧迫骨折と診断され，保 存的加療を行った14名とした。患者の基本属性は, 年 齢76. $4 \pm 10.2$ 歳，身長 $155.1 \pm 7.8 \mathrm{~cm}$ ，体重 $53.4 \pm 9.2$ $\mathrm{kg}$, 腰椎圧迫骨折部位は第 1 腰椎 5 名, 第 2 腰椎 2 名, 第 3 腰椎 4 名, 第 4 腰椎 2 名, 第 5 腰椎 1 名であっ た（椎体骨折判定基準での定量的評価法による内訳； 楔状椎 8 名, 魚椎 5 名, 扁平椎 1 名)。なお，本研究 は社会医療法人緑壮会金田病院倫理試験審査会の承認 を受け，対象患者には学術的使用に関する同意を入院 時に口頭で説明し書面にて同意を得た後に実施した。

\section{2. 方 法}

1 ） MRI 画像による筋脂肪浸潤率の計測

すべての MRI 画像（TOSHIBA 社製 Vantage Titan $3 \mathrm{~T}$ ）は，第 1 腰椎上縁から第 5 腰椎までの上縁と腰 椎上下縁の中間位および仙骨上縁の計11画像とした。 


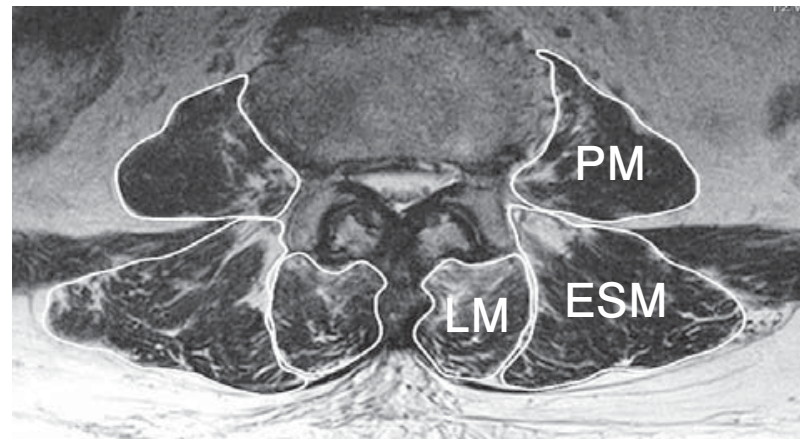

図 1.MRI 画像における腰部多裂筋 (LM), 腰部脊柱起立 筋 $(\mathrm{ESM})$, 大腰筋 $(\mathrm{PM})$

MRI 画像は, T 2 強調画像（fast spin echo,repetition time; 4000msec,echo time; $90 \mathrm{msec}$,field of view ;

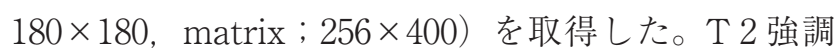
画像は, 主として組織の水分含有量の差を反映した画 像であり，水分を多く含んだ組織が高信号に描出され る。骨格筋は, T 2 強調画像では低信号に, 脂肪は高 信号に描出される。つまり, 計測する筋肉の関心領域

(Region of interest；以下 ROI）において, 高信号に 描出される部分を脂肪浸潤部と判断できる。

脂肪浸潤の計測方法は, Ramson $ら^{20)}$ の先行研究を 参考に行った。各筋肉の ROI お子よび脂肪浸潤の計測 には, 画像処理ソフトウエア Image J1.47を用いて計 測した。各筋肉の ROI は, 水平面の MRI 画像を用い て解剖学的指標を参考にした。計測する筋肉は, 腰部 多裂筋, 腰部脊柱起立筋, 大腰筋とした (図 1$)$ 。こ れらの筋肉は, 左右ともに 2 回計測した。

各筋肉の ROI 計測には, すべて 1 名の理学療法士 が行った。各 ROI は, ウインドウ幅やウインドウレ ベルを変化させ描写し，各ROIにおける pixel あたり の面積を筋断面積とした。各筋断面積 ROI における 脂肪浸潤面積の計測は，0 から255の256階調で数值化 した 8 bit gray scaleにて120以上を脂肪浸潤部と判断 し，その面積の総和を脂肪浸潤面積とした。そして, 筋断面積から脂肪浸潤面積を除した值を算出し, 百分 率で表したものを脂肪浸潤率とした ${ }^{18,20)}$ 。

統計学的分析には, 左右ともに 2 回計測した值の平 均值を左右值とし, その左右值をさらに平均した值を 代表值として使用した。

\section{3. 統計解析}

統計処理に関し，正規性は Shapiro-Wilk の正規性 検定を用いて確認した。しかし, すべての值で帰無仮 説は棄却されず正規性を確認できなかったため non- parametoric 検定を用いることとした。

腰部多裂筋, 腰部脊柱起立筋および大腰筋の各腰椎 の左右差比較は, Wilcoxon の符号付順位和検定を用 いた。

腰部多裂筋，脊柱起立筋および大腰筋脂肪浸潤率の 同一筋内11箇所での差の比較には, 代表值を使用し Kruskal-Wallis 検定で行い, 多重比較には Steel-Dwass 法を用いた。

また, 腰部多裂筋, 脊柱起立筋および大腰筋の同一 䇢所における 3 筋群間の脂肪浸潤率比較には, 代表值 をFriedman 検定で行い, 多重比較にはSteel-Dwass 法を用いた。

骨折部と非骨折部での比較は, 腰椎上縁部位と腰椎 中間位に分け，代表值ならびに左右值別で MannWhitneyのU 検定を用いた。

各筋肉の脂肪浸潤率と BMI の関係を調べるために, Spearmanの順位相関係数を用いて行った。なお，す べての統計学解析は, 統計ソフト EasyR3.1.2を使用 し, 測定值は平均土標準偏差で表示し, 有意確率は $5 \%$ 未満とした。

\section{III. 結 果}

腰部多裂筋, 腰部脊柱起立筋, 大腰筋の各腰椎代表 值および左右值での脂肪浸潤率を表 1 に示す。

各腰椎での左右值比較において, 腰部多裂筋はすべ ての箇所で有意な左右差は認められなかった。一方, 腰部脊柱起立筋では, 第 1 腰椎上縁および中間位（と もに $\mathrm{p}<0.001)$, 第 2 腰椎上縁 $(\mathrm{p}<0.01)$, 第 3 腰椎 上縁（ $\mathrm{p}<0.01 ）$ および中間位 $(\mathrm{p}<0.05)$ ，仙骨上縁 $(\mathrm{p}<0.001)$ で有意な左右差が認められた。大腰筋 では, 仙骨上縁で有意な左右差が認められた $(\mathrm{p}<$ 0. 05)。

同一筋内全11箇所の脂肪浸潤率代表值による比較で は, 腰部多裂筋, 腰部脊柱起立筋, 大腰筋ともに同一 筋内では有意差を認められなかった。

腰部多裂筋, 腰部脊柱起立筋, 大腰筋の同一箇所脂 肪浸潤率代表值における 3 筋群間の比較では, 腰部多 裂筋と腰部脊柱起立筋に有意差は認められなかった。 一方で, 腰部多裂筋と脊柱起立筋は, 大腰筋と比べす べての箇所で有意な高值が認められた（表 2 )。

骨折部と非骨折部での比較は, 腰椎上縁および中間 位での比較では，各筋ともに代表值ならびに左右值別 比較で有意差は認められなかった（表 3 )。

BMI と各筋のすべての椎体箇所の脂肪浸潤率代表 
表 1 ．各筋の代表值および左右值別での脂肪変性率

\begin{tabular}{|c|c|c|c|c|c|c|}
\hline & & & 代表值 & 右值 & 左值 & $\mathrm{P}$ 值 \\
\hline \multirow{11}{*}{ 腰部多裂筋 } & \multirow{2}{*}{ L 1} & 上縁 & $14.1 \pm 13.3$ & $14.7 \pm 13.3$ & $13.5 \pm 13.7$ & 0.326 \\
\hline & & 中間位 & $16.8 \pm 12.5$ & $16.6 \pm 13.5$ & 17. $0 \pm 12.3$ & 0.391 \\
\hline & \multirow{2}{*}{ L 2} & 上縁 & $17.8 \pm 13.3$ & 17. $2 \pm 13.7$ & $18.4 \pm 13.7$ & 0.502 \\
\hline & & 中間位 & $17.7 \pm 17.0$ & $20.0 \pm 24.3$ & $15.3 \pm 11.6$ & 0.626 \\
\hline & \multirow{2}{*}{ L 3} & 上縁 & $19.8 \pm 15.5$ & $18.8 \pm 16.4$ & $20.9 \pm 15.1$ & 0.268 \\
\hline & & 中間位 & $21.9 \pm 17.2$ & $22.0 \pm 18.4$ & $21.9 \pm 17.1$ & 1. 000 \\
\hline & \multirow{2}{*}{ L 4} & 上縁 & $23.5 \pm 15.3$ & $21.8 \pm 17.3$ & $25.2 \pm 15.6$ & 0.502 \\
\hline & & 中間位 & $20.0 \pm 15.8$ & $20.2 \pm 16.3$ & $19.8 \pm 15.6$ & 0.952 \\
\hline & \multirow{2}{*}{ L 5} & 上縁 & $22.6 \pm 17.9$ & $22.8 \pm 18.7$ & $22.4 \pm 17.5$ & 0.834 \\
\hline & & 中間位 & $20.1 \pm 15.1$ & $19.8 \pm 16.0$ & $20.4 \pm 14.8$ & 0.780 \\
\hline & $\mathrm{S} 1$ & 上縁 & $26.5 \pm 11.3$ & $26.9 \pm 13.3$ & $26.0 \pm 9.8$ & 0.855 \\
\hline \multirow{11}{*}{ 腰部脊柱起立筋 } & \multirow{2}{*}{ L 1} & 上縁 & $17.9 \pm 17.7$ & $14.2 \pm 16.1$ & $21.6 \pm 20.1$ & $* * *$ \\
\hline & & 中間位 & $17.4 \pm 16.8$ & $14.5 \pm 15.1$ & $20.4 \pm 18.8$ & $* * *$ \\
\hline & \multirow{2}{*}{ L 2} & 上縁 & $17.4 \pm 17.2$ & $14.6 \pm 15.2$ & $20.2 \pm 19.5$ & $* *$ \\
\hline & & 中間位 & $13.9 \pm 20.6$ & $19.3 \pm 21.3$ & $19.8 \pm 17.3$ & 0.068 \\
\hline & \multirow{2}{*}{ L 3} & 上縁 & 17. $2 \pm 14.4$ & $15.1 \pm 14.0$ & $19.3 \pm 15.4$ & $* *$ \\
\hline & & 中間位 & $19.8 \pm 13.9$ & $18.0 \pm 13.1$ & $21.6 \pm 15.4$ & $*$ \\
\hline & \multirow{2}{*}{ L 4} & 上縁 & $17.6 \pm 11.7$ & $16.2 \pm 10.6$ & $19.0 \pm 13.3$ & 0.091 \\
\hline & & 中間位 & $16.9 \pm 11.9$ & $16.4 \pm 13.0$ & 17. $3 \pm 13.2$ & 0.670 \\
\hline & \multirow{2}{*}{ L 5} & 上縁 & $19.7 \pm 16.0$ & $18.6 \pm 16.5$ & $20.7 \pm 17.0$ & 0.295 \\
\hline & & 中間位 & $19.6 \pm 16.8$ & $17.8 \pm 15.8$ & $21.4 \pm 18.4$ & 0.069 \\
\hline & $\mathrm{S} 1$ & 上縁 & $24.7 \pm 22.6$ & $18.9 \pm 23.7$ & $27.8 \pm 24.9$ & $* * *$ \\
\hline \multirow{11}{*}{ 大腰筋 } & \multirow{2}{*}{ L 1} & 上縁 & $1.1 \pm 1.6$ & $1.1 \pm 1.9$ & $1.2 \pm 1.5$ & 0.965 \\
\hline & & 中間位 & $1.2 \pm 2.1$ & $0.7 \pm 1.3$ & $1.7 \pm 3.0$ & 0.142 \\
\hline & \multirow{2}{*}{ L 2} & 上縁 & $1.2 \pm 2.1$ & $1.7 \pm 3.2$ & $0.8 \pm 1.2$ & 0.415 \\
\hline & & 中間位 & $2.0 \pm 4.0$ & $1.9 \pm 3.9$ & $2.1 \pm 4.1$ & 0.266 \\
\hline & \multirow{2}{*}{ L 3} & 上縁 & $1.2 \pm 1.5$ & $1.0 \pm 1.4$ & $1.4 \pm 1.6$ & 0.068 \\
\hline & & 中間位 & $1.5 \pm 2.5$ & $1.6 \pm 2.7$ & $1.5 \pm 2.5$ & 0.563 \\
\hline & \multirow{2}{*}{ L 4} & 上縁 & $0.9 \pm 1.7$ & $0.7 \pm 1.7$ & 1. $0 \pm 1.8$ & 0.076 \\
\hline & & 中間位 & $1.4 \pm 1.8$ & $1.3 \pm 2.2$ & $1.5 \pm 2.1$ & 0.415 \\
\hline & \multirow{2}{*}{ L 5} & 上縁 & $0.9 \pm 1.4$ & $0.8 \pm 2.0$ & $1.0 \pm 1.4$ & 0.124 \\
\hline & & 中間位 & $0.9 \pm 1.7$ & $0.6 \pm 1.4$ & $1.2 \pm 2.3$ & 0.097 \\
\hline & $\mathrm{S} 1$ & 上縁 & $0.4 \pm 0.8$ & $0.1 \pm 0.3$ & $0.7 \pm 1.4$ & $*$ \\
\hline
\end{tabular}

平均土標準偏差 単位：\%

$\mathrm{L}$ : 腰椎 $\mathrm{S}$ : 仙骨 中間位：椎体上縁と下縁の中間 ${ }^{* * *} \mathrm{p}<0.001 .{ }^{* *} \mathrm{p}<0.01 .{ }^{*} \mathrm{p}<0.05$. (右值 vs 左值)

表 2．同一箇所における 3 筋群間の比較結果

\begin{tabular}{|c|c|c|c|c|c|c|c|c|c|c|c|c|c|}
\hline & & & L 1 上縁 & L1 中間位 & L2 上縁 & L 2 中間位 & L 3 上縁 & L3 中間位 & L4 上縁 & L 4 中間位 & L5 上縁 & L5 中間位 & S1 上縁 \\
\hline 大腰筋 & 対 & 春柱起立筋 & $* * *$ & $* * *$ & $* * *$ & $* * *$ & $* * *$ & $* * *$ & $* * *$ & $* * *$ & $* * *$ & $* * *$ & $* * *$ \\
\hline 大腰筋 & 対 & 多裂筋 & $* * *$ & $* * *$ & $* * *$ & $* *$ & $* * *$ & $* * *$ & $* * *$ & $* * *$ & $* * *$ & $* * *$ & $* * *$ \\
\hline 春柱起立筋 & 対 & 多裂筋 & 0.770 & 0.945 & 0.890 & 0.995 & 0.869 & 1.000 & 0.657 & 0.890 & 0.857 & 0.977 & 0.305 \\
\hline
\end{tabular}

${ }^{* * *} \mathrm{p}<0.001 .{ }^{* * \mathrm{p}}<0.01$.

$\mathrm{L}$ ：腰椎 S : 仙骨 中間位：椎体上縁と下縁の中間 
表 3. 骨折部と非骨折部の腰部多裂筋, 腰部脊柱起立筋, 大腰筋における脂肪浸潤率比較

\begin{tabular}{|c|c|c|c|c|c|}
\hline & & & 骨折部 & 非骨折部 & $\mathrm{P}$ 值 \\
\hline \multirow{6}{*}{ 腰部多裂筋 } & \multirow{3}{*}{ 上縁 } & 代表値 & $16.6 \pm 12.1$ & $21.5 \pm 15.1$ & 0.314 \\
\hline & & 右值 & $16.6 \pm 13.5$ & $21.1 \pm 16.1$ & 0.472 \\
\hline & & 左值 & $16.7 \pm 11.5$ & $21.9 \pm 15.1$ & 0.231 \\
\hline & \multirow{3}{*}{ 中間位 } & 代表値 & $17.8 \pm 12.5$ & $19.7 \pm 15.9$ & 0.879 \\
\hline & & 右值 & $16.5 \pm 13.4$ & $20.5 \pm 18.5$ & 0.668 \\
\hline & & 左值 & $19.1 \pm 12.2$ & $18.8 \pm 14.7$ & 0.799 \\
\hline \multirow{6}{*}{ 腰部脊柱起立筋 } & \multirow{3}{*}{ 上縁 } & 代表值 & $17.2 \pm 12.1$ & $19.5 \pm 17.4$ & 0.976 \\
\hline & & 右值 & $14.1 \pm 11.8$ & $16.5 \pm 17.0$ & 0.826 \\
\hline & & 左值 & $20.2 \pm 13.4$ & $21.4 \pm 19.7$ & 0.726 \\
\hline & \multirow{3}{*}{ 中間位 } & 代表値 & $15.9 \pm 1.1$ & $17.9 \pm 17.0$ & 0.777 \\
\hline & & 右值 & $13.5 \pm 10.3$ & $15.3 \pm 19.3$ & 0.766 \\
\hline & & 左值 & $18.4 \pm 12.5$ & $20.5 \pm 17.2$ & 0.983 \\
\hline \multirow{6}{*}{ 大腰筋 } & \multirow{3}{*}{ 上縁 } & 代表值 & $1.2 \pm 1.6$ & $0.9 \pm 1.5$ & 0.509 \\
\hline & & 右值 & $1.3 \pm 1.9$ & $0.8 \pm 1.9$ & 0.207 \\
\hline & & 左値 & $1.0 \pm 1.5$ & $1.0 \pm 1.5$ & 0.951 \\
\hline & \multirow{3}{*}{ 中間位 } & 代表値 & $1.1 \pm 1.9$ & $1.5 \pm 2.6$ & 0.790 \\
\hline & & 右值 & $0.7 \pm 1.3$ & $1.3 \pm 2.7$ & 0.653 \\
\hline & & 左值 & $1.4 \pm 2.6$ & $1.7 \pm 2.9$ & 0.976 \\
\hline
\end{tabular}

単位：\%

中間位：椎体上縁と下縁の中間

表 4 、腰部多裂筋，腰部脊柱起立筋，大腰筋の脂肪浸潤率と BMI との相関関係

\begin{tabular}{|c|c|c|c|c|c|c|c|c|c|c|c|}
\hline & \multicolumn{2}{|c|}{ L 1} & \multicolumn{2}{|c|}{ L 2} & \multicolumn{2}{|c|}{ L 3} & \multicolumn{2}{|c|}{ L 4} & \multicolumn{2}{|c|}{ L 5} & \multirow{2}{*}{$\begin{array}{l}\mathrm{S} 1 \\
\text { 上縁 }\end{array}$} \\
\hline & 上縁 & 中間位 & 上縁 & 中間位 & 上縁 & 中間位 & 上縁 & 中間位 & 上縁 & 中間位 & \\
\hline 腰部多裂筋 & 0.108 & 0.266 & 0.046 & 0.086 & -0.156 & 0.007 & 0.081 & 0.099 & -0.297 & -0.248 & -0.437 \\
\hline 腰部脊柱起立筋 & 0.103 & 0.020 & 0.015 & -0.178 & -0.495 & -0.477 & -0.235 & -0.143 & -0.429 & -0.455 & -0.222 \\
\hline 大腰筋 & -0.135 & -0.024 & 0.122 & 0.024 & 0.055 & -0.170 & 0.043 & -0.342 & -0.034 & -0.061 & 0.085 \\
\hline
\end{tabular}

$\mathrm{L}$ : 腰椎 $\mathrm{S}$ : 仙骨 中間位 : 椎体上縁と下縁の中間

值とは，有意な相関関係は認められなかった（表 4$)$ 。

\section{IV. 考 察}

本研究では腰部多裂筋以外に, 腰部脊柱起立筋と大 腰筋を計測した。腰部脊柱起立筋は，脊柱のトルク生 成と方向性の制御能力に関わり脊柱全体の剛性を高め る。そして, 大腰筋は, 腰部多裂筋と協調筋として骨 盤前傾と腰椎前彎に作用する ${ }^{21}$ 。そのため, 腰椎前彎 に関わり可動性低下や骨盤帯の姿勢変化に起因してい る筋肉として計測した。これらの筋における腰椎11䇢 所で計測した脂肪浸潤率代表值の結果は, 腰部多裂筋 $14.1 \sim 26.5 \%$, 春柱起立筋 $13.9 \sim 24.7 \%$, 大腰筋 0.4 〜 $2.0 \%$ とった。この結果は, 本研究で対象とした 腰椎全域の脂肪浸潤率を定量的に確認できたと考えて いる。

筋肉の脂肪浸潤に関して，その一因に加齢や不活動
による影響以外に骨折や関節損傷による反射抑制, 疼 痛抑制によっても生じるとされる22)。本研究では, 骨 折部と非骨折部に分け, 腰部多裂筋の代表值および左 右值別で比較した。結果, すべての值で骨折部と非骨 折部では有意差は認められなかった。この結果は, 腰 部脊柱起立筋㧍よび大腰筋でも同様の結果となった。 本研究の対象患者については, 骨折に関係なく腰椎多 裂筋抢よび腰部脊柱起立筋，大腰筋の脂肪浸潤が生じ ていると考えられた。また, 本研究の腰椎圧迫骨折患 者は, 椎体骨折判定基準での定量的評価法による内訳 で，楔状椎掞よび魚椎が多かった。つまり，椎体後方 への影響が少ないことが考えられ, 神経根への圧迫や 損傷による影響が少なかったことが一つに考えられた。

次に, 各筋肉の形態学的特徵として, 各椎体レベル で異なるとされる。腰部多裂筋は尾側に向かうに従い 増加し, 腰仙椎移行部で最大となる。一方で, 脊柱起 
立筋は，腰部多裂筋とは逆に尾側に向かって減少する。 大腰筋は，第 4 腰椎と 5 腰椎間に筋腹があるとされる。 しかしながら, 本研究のすべての筋肉の脂肪浸潤率に おいても，第 1 腰椎から仙骨上縁までの同一筋内での 比較において有意差は認められなかった。よって, 脂 肪浸潤率には, 筋形態学的な特徵と関係なく腰椎全域 で同程度に脂肪浸潤が生じていることが認められた。 以上のことより，骨折による急性的な影響は少なく, 腰痛や椎間板ヘルニア患者のような限局的な腰部多裂 筋脂肪浸潤と異なった脂肪浸潤の影響と考えられた。

この腰部多裂筋および腰部脊柱起立筋の $10 \%$ 以上の 脂肪浸潤率には, 腰椎可動域低下が一因と考えられる。 加齢に伴い腰椎伸展可動域は, 男性と比較し女性で低 下し, 腰椎前彎の減少をともなうことが報告されてい $ろ^{232{ }^{24)}}$ 。Anderson ら ${ }^{17}$ は, 特に女性は加齢により腰部 金柱起立筋において脂肪浸潤しやすいとしている。こ の腰椎前彎減少は, 体幹伸展筋活動の低下を生じさせ ることが考えられる。本研究の対象者は, 76.4歳と高 齢女性であり, 加齢にともなう腰椎可動域制限と腰椎 前彎の減少も考えられる。そのため, 加齢に伴う腰椎 前彎の低下と腰背部筋の筋活動低下を反映し, 腰部多 裂筋㧍よび腰部脊柱起立筋の $10 \%$ 以上の脂肪浸潤率結 果となった可能性が考えられた。

また，筋肉の脂肪浸潤率に関して, Fukumoto ら ${ }^{13)}$ は体脂肪率や BMI などでは予測できないと報告して いる。本研究では, 体脂肪率と有意な相関関係にある BMI と各筋肉の脂肪浸潤率代表值には有意な相関関 係は認められなかった。このことは, BMI と各筋肉 の脂肪浸潤率に関係性は低いことを支持する結果と考 えられた。

筋肉の脂肪浸潤率の左右值比較では, 腰部多裂筋で は有意な左右差は認められなかった。一方で, 脊柱起 立筋脂肪浸潤率は, L 1 上縁から L 3 中間位で有意な 差を認めた。よって, 腰部脊柱起立筋の左右差に加え, 脊柱起立筋および腰部多裂筋の腰椎全域の脂肪浸潤の 増加は, 体重や重力によって産生される大きな負荷に 対抗し, 脊柱の安定性を保つための筋力が低下し, 脊 椎およびそれに関わる関節への過剩なストレスが加わ りやすい状態であった可能性が考えられた。

各腰椎における同一箇所の脂肪浸潤率を多重比較検 定した結果は, 腰部多裂筋および腰部脊柱起立筋は大 腰筋と比べ全箇所で有意に高率を認めた。脂肪浸潤程 度の違いの一つには, Type 線維の違いがあり筋活動 低下にともない筋 Type I 線維の比率が高いほど組織
変化しやすいという報告がある ${ }^{15)}$ 。そのため, 本研究 において Type I 線維の分布比率が高い腰部多裂筋お よび腰部脊柱起立筋は, Type II 線維の分布比率が高 い大腰筋と有意に異なる脂肪浸潤率になったと考えら れた。

本研究の限界として, 腰部圧迫骨折患者を対象に 行ったが, 健常者との比較がなく, サンプルサイズが 小さいことからも腰部圧迫骨折患者の腰背部筋におけ る脂肪浸潤程度の一般化には慎重に適応する必要があ る。さらに本研究では, 筋脂肪浸潤率に絞っての計測 を行い, 実際の体幹筋機能として筋力との関連は不明 である。また，骨盤アライメントの評価およびそれに 寄与する筋群の活動を評価していないため，10\%以上 の腰部多裂筋および腰部脊柱起立筋の脂肪浸潤率が生 じている因子についての検証は不十分であり, 今後の さらなる研究が必要と考える。

\section{引用文献}

1）八木宏明, 砥上恵幸, 富永俊克・他: 春椎圧迫骨折患者に おける椎体骨折数と移動および日常生活動作能力との関係 についての検討. 日本職業・災害医学会誌, 2012，60：353 -356 .

2) 森諭史: 骨粗鬆症患者の椎体圧迫骨折, 脊椎変形と ADL 低下の関連. 日本腰痛学会雑, 2002, 8 : 58-63.

3 ) Hagino H, Nakamura T, Fujiwara S, et al. : Sequential change in quality of life for patients with incident clinical fractures : a prospective study. Osteoporos Int, 2009, 20(5): 695-702.

4) Silverman SL, Minshall ME, Shen W, et al. : The relationship of health-related quality of life to prevalent and incident vertebral fractures in postmenopausal women with osteoporosis : results from the Multiple Outcomes of Raloxifene Evaluation Study. Arthritis Rheum, 2001, 44(11): 2611-2619.

5 ) Bliuc D, Nguyen ND, Milch VE, et al. : Mortality risk associated with low-trauma osteoporotic fracture and subsequent fracture in men and women. JAMA, 2009, 301(5): 513521.

6 ）福田敦美, 原田和宏, 二瓶健司・他：女性高齢者に扔ける 脊柱弯曲角度と身体諸機能・転倒歴の関連性. 理学療法学, 2013, 40(7) : 465-472.

7 ) Claus AP, Hides JA, Moseley GL, et al. : Different ways to balance the spine : subtle changes in sagittal spinal curves affect regional muscle activity. Spine. 2009, 34(6): 208-214.

8) Fujiwara S, Kasagi F, Masunari N, et al. : Fracture prediction from bone mineral density in Japanese men and women. J Bone Miner Res, 2003, 18: 1547-1553.

9 ) Sinaki M, Itoi E, Wahner HW, et al. : Stronger back muscles reduce the incidence of vertebral fractures: a prospective 10 year follow-up of postmenopausal women. Bone, 2002, 30: 836-841. 
10) Bliuc D, Nguyen ND, Milch VE, et al. : Mortality risk associated with low-trauma osteoporotic fracture and subsequent fracture in men and women. JAMA, 2009, 301(5): 513521.

11) Singer KP, Breidahl P.: The Use of Computed Tomography in Assessing Muscle Cross-sectional Area and Strength. Aust J Physiother, 1987, 33(2): 75-82.

12) Fukunaga T, Roy RR, Shellock FG, et al. : Specific tension of human plantar flexors and dorsiflexors. J Appl Physiol, 1996, 80(1): 158-165.

13) Fukumoto Y, Ikezoe T, Yamada Y, et al. : Skeletal muscle quality assessed from echo intensity is associated with muscle strength of middle-age and elderly persons. Eur J Appl Physiol, 2012, 112(4): 1519-1525.

14) Delmonico MJ, Harris TB, Visser M, et al. : Longitudinal study of muscle strength, quality, and adipose tissue infiltration. Am J Clin Nutr, 2009, 90(6): 1579-1585.

15）光武翼, 中田裕治, 大石豪 - 他 : 頚椎症性神経根症患者に おける頸部伸筋群の脂肪浸潤と平行機能との関係：MRI を用いた頸部多裂筋および僧帽筋上部繊維の筋内脂肪計測. 理学療法学, 2014, 41(2)：66-74.

16) Visser M, Goodpaster BH, Kritchevsky SB, et al. : Muscle mass, muscle strength, and muscle fat infiltration as predictors of incident mobility limitations in well-functioning older persons. J Gerontol A Biol Sci Med Sci, 2005, 60(3): 324-333.

17) Anderson DE, D'Agostino JM, Bruno AG, et al. : Variations of CT-based trunk muscle attenuation by age, aex, and specific muscle. J Gerontol A Biol SciMed Sci, 2013, 68(3): 317323.

18) Pezolato A, de Vasconcelos EE, Defino HL, et al. : Fat infiltration in the lumbar multifidus and erector spinae muscles in subjects with sway-back posture. Eur Spine J, 2012, 21(11): 2158-2164.

19) Kim JY, Chae SU, Kim GD, et al. : Changes of paraspinal muscles in postmenopausal osteoporotic spinal compression fractures: magnetic resonance imaging study. J Bone Metab, 2013, 20(2): 75-81.

20) Ranson C, Burnett A, Kerslake R, et al. : An investigation into the use of MR imaging to determine the functional cross sectional area of lumbar paraspinal muscles. Eur Spine J, 2006, 15(6): 764-773.

21）石井慎一郎：骨盤帯を中心とした運動連鎖の理解. 理学療 法, 2015, 32(11)：973-980.

22) Richardson C, Hodges PW, Hodges PW. : 腰痛に対するモー ターコントロールアプローチー腰椎骨盤の安定性のための 運動療法. 斎藤昭彦 (訳), 医学書院, 東京, 2008, 107126.

23) Dreischarf M, Albiol L, Rohlmann A, et al. : Age-related loss of lumbar spinal lordosis and mobility-a study of 323 asymptomatic volunteers. PLOS One 2014; 9(12): e116186.

24) Amonoo-Kuofi HS. Changes in the lumbosacral angle, sacral inclination and the curvature of the lumbar spine during aging. Acta Anatomica, 1992, 145: 373-377. 